\title{
The Moral Dimension of the Religiosity of Poles in an Era of Systemic Change
}

This article discusses specific statistical indicators of the moral dimension of the religiosity of contemporary Poles. Survey results show that, although the majority of respondents (59\%) favor the need to ascribe to moral principles, they are willing to compromise their principles in certain circumstances. Nearly half (48\%) of the respondents claimed to be guided by their own consciences and rejected the need to substantiate their morals via religion. Seventy-one percent of the respondents believed that Catholic moral principles are legitimate, but not all of the respondents agreed on which principles. With regard to the specific norms of Catholic teaching on marriage and family ethics, very few respondents agreed with the Church's teaching against pre-marital sexual relations and the use of birth control, while more respondents respected the Church's teaching on the value of marital fidelity, the permanence of marriage, and respect for life conceived in the womb. Taken together, these statistics reveal that contemporary social changes have deepened the already-existing gap between the daily practice of religion and morality in Poland.

Key words: religiosity, morality of religion, moral norms, pluralism, systemic change.

The social changes that the Solidarity movement initiated in Poland came to a climax in 1989 when the communist regime was electorally defeated. At that time, systemic social, cultural, economic, and political changes began to take place on both the macro and micro levels, which affected both the public and private spheres of Polish life. The fidelity of Poles to religious practice and morals is an important component of this change. The scope and dynamics of the changes that 
Pastoral theology

occurred in the religiosity of poles are often referred to in terms of secularization vs. desecularization, privatization vs. deprivatization, and institutionalization vs. individualization of attitudes toward religion. Sociologists, psychologists, and pedagogues have posed questions regarding changes in religiosity. Pastoral theologians, who have also come to recognize and analyze the current socio-cultural changes and contemporary context, have also posed their own questions. The aim of this article is to answer the following question: What does the religiosity of Poles in the area of morality look like in the context of the systemic changes that have occurred in Poland since the fall of communism? The response to this question requires that two concepts on which this topic is based be clarified in the following paragraphs.

In Poland, sociological studies on religiosity rely heavily on P. Piwowarski's sociological definition of religion, which can be used in empirical research. This definition was created from a compilation of thoughts of Western sociologists of religion. ${ }^{1}$ Sociological studies treat moral attitudes and behavior, which will continue to be the subjects of further analyses, as consequences of religiosity. Among sociologists and psychologists of religion, however, there is not one way to understand this dimension. Charles Glock and R. Stark both write on the classical concept of religiosity and include in it all religious principles that determine how people should act, particularly those principles arising from the religion a given person chooses to follow. This classical concept concerns the effects that an individual's religious convictions, experiences, and knowledge have on the secular areas of his life. The authors themselves differentiate this parameter in the operationalization of religiosity and realize that it is not possible to clearly define which activities fall within the scope of religious commitment and which ones result from it. ${ }^{2}$ Although the relationship between religiosity and morality seems obvious to everyone, this issue is still a topic of lively discussion. Only extreme approaches uphold that religiosity and morality are either very closely connected

$1 \quad$ According to Piwowarski,"religion is a system of beliefs, values, and related actions that are fulfilled by a group of people. They arise from the distinction between empirical reality and non-empirical reality as well as from attributing empirical reality to matters that are not empirical reality." He distinguishes the following parameters in the operationalization of this concept: the global approach to faith, religious knowledge, religious ideology, religious experience, religious practices, religious community, and religious morality. W. Piwowarski, Socjologia religii, Lublin 2000, pgs. 43 and 65.

2 R. Stark, C. Glock, Wymiary zaangażowania religijnego, in Socjologia religii. Antologia tekstów., W. Piwowarski (ed.), Cracow 1998, pg. 185. 
or completely autonomous. The majority of authors take a moderate position; while they are not opposed to these two dimensions of life, they do not acknowledge them either. ${ }^{3}$

\section{Morality Within the Context of the Structural Changes that Occurred in Poland After 1989}

Identifying the process of change that has occurred in Poland from a sociological point of view is not an easy task. Researchers have analyzed the issue on several levels, and they have identified changes that have taken place within Europe and globally that have affected Polish society. Factors that are unique to Poland are also important, including the socialistic system that was in place when the changes began as well as new phenomena and processes related to the Round Table Agreement; the establishment of a liberal democracy, a free market economy, and a civil society; and Poland's integration into the European Union. ${ }^{4}$ The structural changes that occurred with political change, at least during the first phase of change after the fall of communism, are also important in understanding whether people respect moral norms and specific behaviors. These structural changes concern situations that had not previously occurred, such as: unemployment, poverty, and social exclusion. Diversification in the labor market, which continues to increase, has arisen out of new sectors of production as well as new forms of economic organization. Among Poles who are able to become highly qualified specialists and enjoy a certain employment status, are able to be promoted, and earn a high income, there are also those who work only part-time, are self-employed, and work multiple jobs. Changes that have occurred in the economy have also caused both uncertainty and a sense of instability. The labor market involves flexible forms of employment, McJobs, the gray zone, and the working poor. The latter account for $8 \%$ of the population of the EU, but in Poland, however, they constitute $13 \% .{ }^{5}$ For a long time, people have spoken openly about the successful and failed political changes that have taken place in Poland. And, among the strategies that people

3 R. Boguszewski, Religia i moralność, in Leksykon socjologii moralności. J. Mariański (ed.), Cracow 2015, pgs. 669-660.

$4 \quad$ E. Wnuk-Lipiński, M. Ziółkowski, Założenia teoretyczne, in Pierwsza dekada niepodległości. Próba socjologicznej syntezy, E. Wnuk-Lipiński, M. Ziółkowski (eds.), Warsaw 2001, pgs. 16-31.

5 Ł. Krzyżanowska, M. Stec, Rynek pracy, in Wspótczesne społeczeństwo polskie, A. Giza, M. Sikorska (eds.), Warsaw 2013, pgs. 537-539. 
Pastoral theology employ in order to adapt to these changes, there are behaviors that do not pertain to private, social, and civic morality. ${ }^{6}$

Contemporary changes are evident in structural and functional differentiation. In other words, Polish society has become more decentralized. Many social groups that have different views and uphold different values, preferences, and norms exist in Poland, ${ }^{7}$ and individualization in creating one's own biography, ways of living, and personal identity has increased. These phenomena are also influencing morality, including Poles' general moral orientation as well as how they morally evaluate concrete situations and matters. For a long time, the social sciences have used the term "second modernity" to describe these changes. This second modernity is characterized by an internal globalization that pertains to work, culture, the economy, personal experiences, and life biographies. A further symptom of this modernity is the individualization evident in the possibility of making different choices and having a variety of options from which to choose. As a result of this individualization, traditional social bonds and belief systems have gradually become irrelevant, the economy has become more risky, and the modern division between nature and culture has been blurred. ${ }^{8}$ This process of individualization is evident in Poles' moral life, religiosity, and how they construct their own biographies. This process entails not only liberation from the determinants that have existed thus far, but also new forms of social addictions. As $\mathrm{Z}$. Bauman points out, individualization is our fate, and it gives people more freedom to experiment and simultaneously holds them responsible for the consequences of these experiments. The contradictions arising from modernity can been seen in the gap between the right to determine one's future and the ability to exercise control over social conditions that either enable or take away such self-determination. ${ }^{9}$

Polish society undoubtedly displays many of the features of a postmodern society in which progressive structural and functional differentiation has occurred and where people belong to many separate social subsystems. People uphold and manifest different attitudes,

A. Jasińska-Kania, Przeksztatcenia moralności w Polsce i Europie, in Wymiary życia społecznego. Polskana przetomie XXi XXI wieku, M. Marody (ed.), Warsaw 2004, pgs. 401-411.

7

J. Mariański, Religia i moralność w świadomości Polaków: Zależność czy autonomia?, "Konteksty społeczne," vol. 3 (2015) no. 1, pg. 8

T. Szlendak, Socjologia rodziny. Ewolucja, historia, zróżnicowanie. Warsaw 2011, pgs. 401-402. 
views, moral norms, behavioral patters, and values depending on which subsystem they belong to. As stated above, individualization in shaping one's own life story and personal identity has grown stronger. Sociologists describe this as a transition from a society of fate to a society of choice. A society of fate is one governed by a kind of determinism; it lacks options, alternatives, and choices. For example, an individual's attitudes, even in the realm of religion, are formed by traditions that social and religious institutions impose. A society based on choice, on the other hand, provides a multitude of options and alternatives, even in situations where making a choice is imperative. ${ }^{10}$

Social diversity leads to structural and cultural pluralism. In structural pluralism, many social groups and institutions whose diversity is due to their role in society exist and compete with each other. Structural pluralism is where worldviews, philosophies of life, and systems of meaning compete with each other. ${ }^{11}$ During the Polish People's Republic, cultural pluralism arose mostly in individual's subjective consciousness and, to a lesser degree, in social institutions and specialized groups. Since the inception of the Polish People's Republic, cultural pluralism has gained institutional support from parties, organizations, social groups, and minorities. It is no wonder, therefore, that organized and institutionalized activities that center around some politicians, groups, or powerful medial broadcasters foster negative attitudes and outright hostility toward religion, the Catholic Church, Christian values, and Catholic circles. In this context, contemporary pluralism has become a basic social value to such a degree that it requires individuals to be tolerant of all views, activities, and behaviors. ${ }^{12}$

A postmodern mentality that: a) negates the existence of objective truth, which in turn evokes an aversion to individuals and social institutions that declare that they are certain about their convictions, encourages individuals to move away from institutionalized religions, and shifts religious issues to the private sphere of life; b) questions values and norms rooted in tradition, which includes undermining traditional authorities and giving into theories and beliefs that the mass media presents; c) absolutizes the idea of tolerance, where every orientation of life demands the right to be respected without consideration for intersubjective values; $d$ ) promotes moral pluralism and

10 W. Piwowarski, Przemiany Kościoła ludowego w Polsce, "Przegląd Humanistyczny" 4:1997, pg. 18.

11 W. Piwowarski, Socjologia religii, pgs. 360, 369.

12 K. Święs, "Aktualne uwarunkowania nowej ewangelizacji w Polsce," in Polskie drogi nowej ewangelizacji. K. Święs, D. Lipiec (eds), Lublin 2014, pgs. 34-35. 
Pastoral theology

relativism; and e) commercializes many areas of social life, including religion, and encourages a consumer lifestyle is becoming more and more prevalent within Polish culture. ${ }^{13}$

Changes in religiosity are an important element of the processes mentioned above, which are not isolated from the whole of social life. According to many sociologists, concepts of social change manifest numerous trends that can help them interpret the religiosity of Polish society, while the character of Polish Catholicism makes it possible for them to explain many of the phenomena of Polish sociocultural changes. ${ }^{14}$ As a cultural asset, Catholicism can shed light on specific transformations that have occurred in Polish values, culture, and consciousness. ${ }^{15}$ Pastoral theology questions the repercussions of social change in Polish attitudes toward religion and the Church's role in a pluralistic society. The changes in contemporary religiosity in Poland challenge the Church to be more actively and intensely engaged in its mission to the world.

\section{General Moral Orientations}

Research on morality often poses questions related to the general moral criteria that inform and guide people's behavior. This research seeks to determine whether people ascribe to and follow unchanging moral principles, or whether they have a relativistic approach to ethical principles and modify their behavior based on circumstances. Theologians and moralists emphasize that man's moral activity involves cognition and consideration of the moral order as well as the free decision to act in accordance with this order. In this way, personal choice is a tangent point for norms that arise from the objective order and subjective authority known as the conscience. ${ }^{16}$ When describing moral convictions, it is necessary to point out the attitudes that people have toward general ethical norms. In every environment,

$13 \quad$ Z. Sareło, Postmodernizm w pigutce, Poznań 1998, pgs. 27-31.

$14 \quad$ I. Borowik, T. Doktór, Pluralizm religijny i moralny $w$ Polsce. Raport z badań, Cracow 2001, pg. 21.

15 In a survey conducted by the Institute on Catholic Church Statistics [Instytut Statystyki Kościoła Katolickiego] in 2012, 20.1\% of respondents considered themselves deeply faithful, $60.8 \%$ described themselves as believers, $10.3 \%$ described themselves as undecided but attached to tradition, $5.4 \%$ said they were indifferent to religion, and $2.9 \%$ said that they did not believe. See E. Jarmoch, Wiara i religijność, in Postawy społeczno-religijne Polaków 1991-2012, (eds.) L. Adamczuk, E. Firlit, W. Zdaniewicz, Warsaw 2013 pg. 34 [29-57].

S. Rosik, Wezwania i wybory moralne, Lublin 1992, pg. 102. 
people create a variety of norms that regulate definitive areas of life. In fact, people adopt different norms as the basis for their moral orientation. Postmodern society generally does away with clear distinctions regarding what is morally good and morally bad and denies that absolute moral values exist. Recent sociological studies of religion have rarely asked whether Poles are aware of the existence of clear, objective moral criteria that can determine what is good and what is bad in every situation. Earlier studies from 2005, however, indicate Pastoral that $21.1 \%$ of Polish youth believed that objective moral criteria exist, whereas in 2009 , only $14.2 \%$ of high school graduates from five Polish cities acknowledged the existence of such criteria. In 2005, 54.6\% of young Poles and $67.6 \%$ of high school graduates were of the opposite opinion as those questioned in 2009. ${ }^{17}$

The scope of fundamental or purposeful attitudes also reveals peoples' general moral orientations. The former indicates the acceptance or negation of some kind of a rule that refers to a real or possible action. In the case of latter, accepting or negating a rule for behavior depends on weighing a variety of possible behaviors and assessing their effects. ${ }^{18}$ Sociology does not ethically evaluate these attitudes in terms of good or evil, even though they may concern a moral good or evil. Rather, these behaviors have an empirical value in sociology of morality. ${ }^{19}$ For example, a poll conducted by the Centrum Badania Opinii Społecznej [Center for Public Opinion Research; hereafter abbreviated as CBOS] in February 2009 revealed that, among Polish adults, $31 \%$ believed that they should uphold solid moral principles from which they should never deviate; $39 \%$ admitted that people should have clear moral values but that they can renounce these values in exceptional situations; $16 \%$ said that people should uphold some moral principles but that there was nothing wrong with going against them if life circumstances made it necessary; $9 \%$ believed that a people's behavior should not be determined by set moral principles, but that individuals should seek the right way to behave and proceed depending on the situation; and $5 \%$ were undecided. In a similar survey that took place in December 2013, the results (which corresponded to the categories of the previous poll) were as follows:

17 J. Mariański, Przemiany moralności polskich maturzystów w latach 1994-2009. Studium socjologiczne, Lublin 2011, pgs. 2011-2014.

18 A. Podgórecki, Socjologiczna teoria prawa, Ł. M. Kwaśniewska, R. Smogór (trans.), Warsaw 1998, pgs. 51-52.

19 J. Mariański, Religia i moralność w świadomości Polaków. Zależność czy autonomia?, “Konteksty społeczne," Vol. 3 (2015) no. 1, pg. 10. 
Pastoral theology

$22 \%, 42 \%, 19 \%, 12 \%$, and $5 \%$. Three years later, in November 2016, the results were as follows: $21 \%, 39 \%, 20 \%, 12 \%$, and $8 \%$. Therefore, from 2009-2016, the number of those who believe that a person should always have clear moral principles and should never deviate from following them fell by $10 \%$. On the other hand, the number of individuals who believe that a person can renounce his moral principles in certain circumstances increased by $4 \%$. Except for those who regularly practice their religion the most and who have clear and absolute moral values, ${ }^{20}$ almost every socio-demographic group believed that people should have certain moral principles but that they can violate these principles in exceptional situations.

In Poland, the moral dimension of religiosity is influenced by the Church's pastoral work and catechesis. Today, the Roman Catholic Church and other Christian churches no longer exclusively shape human behavior and they must now compete in this regard with other institutions. As L. Dyczewski observes, "the processes of secularization and desacralization have made it such that the Church and religion regulate the rhythm of life of many individuals, families, and all of society to a lesser degree than before. In turn, these processes have led to the secularization of customs and of a culture that does not observe Sundays and holy days, and have weakened and even taken away the average person's awareness of divine principles. These processes also spread the idea that everything is possible for the human person. Man's attitude toward the sacred is changing. [...] Different kinds of cults are appearing in place of religion. Together these processes constitute the phenomenon of secularization."21 A manifestation of these changes can be seen in the weakening of the relationship that exists between professing a faith and upholding certain moral convictions and behaviors.

In this context, it is important to consider what Poles think the sources of general moral principles are. In other words, what do Poles think the relationship between religion and morality is and, indirectly, what do they think the source for the justification of moral norms is? In 2009, among Polish adults, $24 \%$ were convinced that only religion can justify legitimate moral demands; $38 \%$ believed that religion justifies their own moral precepts; $33 \%$ did not feel like religion was necessary to justify their morals and were convinced that their own conscience was sufficient; and 5\% were not interested in this issue.

\footnotetext{
20 Moral Principles and Religion, A Message from the CBOS, nr 4/2017, Warsaw 2017, pg. 2. Edited by R. Boguszewski.

21 L. Dyczewski, Kultura w całościowym planie rozwoju, Warsaw 2011, pgs. 55-56.
} 
When the same survey was conducted in December 2013, the following results regarding the same questions were obtained: $16 \%, 33 \%, 41 \%$, and $10 \%$. And in November 2016, a similar survey revealed the following responses: $12 \%, 30 \%, 48 \%$, and $10 \%$. A $12 \%$ decline in those who perceived religion as the only source of justification for the right moral demands was observed. The proportion of people who felt that their own conscience rather than religion is sufficient to justify the morality of certain behaviors increased considerably by $15 \%$. Moreover, in theology the last three years, this has become the predominant position held by the majority of the population that participated in the survey. It is reasonable, therefore, to hypothesize that these individuals created (or, if they have not already, will create) their own moral system that exists completely outside of the Church. It is empirically clear that modern Polish society does not believe that moral values and norms, especially those based on religious tradition, are as important as they did in the past, and pluralism and relativism have become predominant in the moral consciousness of Poles. According to this consciousness, a person's own choice and pragmatic criteria are used to determine personal conduct rather than objective and categorical moral norms. ${ }^{22}$ In short, moral principles that inform Poles' concrete personal behavior is being replaced by individualism, which emphasizes an individual's freedom and autonomy in making his own life choices.

When speaking about the moral dimension of religiosity, it is worthwhile to inquire into Catholicism's moral principles and to examine to what extent the behavior of faithful Catholics is consistent with the Catholic Church's normative expectations regarding morality. In response to a nationwide survey that was conducted in Poland in $2006,31 \%$ of respondents acknowledged that Catholic moral principles are the best and sufficient; $26 \%$ supported the claim that all Catholic principles are correct, but that, when faced with complex life situations, they could be supplemented by other moral principles; $36 \%$ agreed that the majority of Catholic moral principles are correct, but that they do not agree with all of them and that, those moral principles that are correct are insufficient in themselves; $5 \%$ confirmed that they are unfamiliar with religious morality, but that some Catholic moral principles are right; and the remaining $1 \%$ claimed that they are completely unfamiliar with Catholic moral principles. In 2009, the same survey revealed that, among all adult Poles, the percentages that correspond with the aforementioned categories were as follows: $24 \%$,

$22 \quad$ M.Ziółkowski, Zmiany systemu wartości, in Wspótczesne społeczeństwo polskie. Dynamika zmian, J. Wasilewski (ed.), pg. 145. 
Pastoral theology

$30 \%, 37 \%, 5 \%$, and $3 \%$. When the same survey was conducted in 2013 , it yielded the following results: $18 \%, 27 \%, 45 \%, 7 \%$, and $3 \%$, respectively. In 2016 , the results of the survey remained practically unchanged at: $18 \%, 25 \%, 46 \%, 8 \%$, and $3 \%$. The distribution of the data demonstrates that the increasing majority of Poles consider almost all of the Catholic moral principles to be correct, but they do not agree with all of them. This conviction is evident in specific practical attitudes. In a pluralistic society, relativism and moral permissiveness are becoming more predominant. Relativism, which is often linked to situational ethics, asserts that absolute truth or morality that is universally binding does not exist. Therefore, individual sociocultural and economic factors determine the principles of moral behavior.

Many studies have confirmed the thesis that religiosity functions on two levels in Polish society. First, it functions as the faith of the nation. Second, it functions as the religion of peoples' everyday life, which manifests itself particularly in the area of morality. Not only some Catholics question the moral principles of the Catholic Church's doctrine, but also those who are otherwise regarded as deeply religious. Sociocultural changes, pluralism, individualization, and rationalization contribute to the different moral orientations. When Poland changed from a totalitarian state to a democracy, the processes of spontaneous secularization intensified. The position and role of the Church in Polish society as well as changes in religiosity among Poles today manifest this change. ${ }^{23}$ Another aspect of these changes is the shift that has occurred in the nature of the relationship between religious and moral values. In this sense, the process of the autonomization and individualization of morality is evident, particularly in the separation of morality from religion. When describing these phenomena, P. Neuner notes that, "in today's world there are no longer areas that have established rules of conduct. Instead, alternatives are possible in every area of life, everything can be different, and many things can be done in differently. [As a result,] everybody constantly has to make decisions and choices. With their inexhaustible offerings, supermarkets are a symbol not only of the choices that can be made when shopping, but also the choices that are available in life in general." ${ }^{24}$ Therefore,

${ }_{23}$ W. Piwowarski, "Od Kościoła ludu do Kościoła wyboru,” in Od Kościoła ludu do Kościoła wyboru. Religia a przemiany społeczne w Polsce, I. Borowik, W. Zdaniewicz (eds), Cracow 1996, pg. 16.

24 P. Neuner, Psychospołeczne i polityczne uwarunkowania chrześcijaństwa dziś, in Chrześcijaństwo jutra. Materiaty II międzynarodowego kongresu teologii 
the fundamental question is: What are the consequences of these processes on specific views and behaviors?

\section{Attitudes Toward Moral Norms Pertaining to Marriage and the Family}

The previous section selectively presented the surveys results re- Pastoral garding Poles' general moral orientation. This section will focus on theology the attitudes that Poles have toward specific moral norms, particularly Catholic moral norms pertaining to the ethics of marriage and family life. There are three reasons for narrowing the scope of this discussion: 1) within the scope of this article it is impossible to discuss all issues pertaining to the moral dimension of religiosity; 2) the Church regularly teaches on marriage and the family in catechesis, homilies, and marriage preparation, and modernity puts a lot of pressure on families and how they function; and 3) the vast majority of studies describe the parameter of religiosity based on questions that facilitate access to results. In the very concept of attitudes, the emotional-evaluative element along with the lasting beliefs regarding the properties of the subject of these attitudes and the dispositions to behave in a certain way toward this subject are essential. Already in the very concept of attitudes, the emotional-evaluating element and the persistent beliefs about the properties of the posture associated with it, as well as the dispositions to behave towards this object are important. ${ }^{25}$ Based on the attitudes that the respondents have toward moral norms, one can infer that they respect particular values in their individual and social lives. In this way, moral norms guard values and are the means to realize them. ${ }^{26}$ Do Pole's attitudes toward marriage and family confirm the moral orientations presented above?

Sociologists often discuss the structural and cultural changes that are taking place in the family today. The former concerns increasing family instability, the dissemination of new ways of living (cohabitation, incomplete families), limiting the number of children in a family, the changing social roles of spouses, and the position of children in a family. All of these are the consequence of the complex process of transformation that has occurred in human consciousness over time

fundamentalnej. Lublin (September 18-21, 2001), M. Rusecki et al (eds.), Lublin 2001, pg. 255.

S. Nowak, Pojęcie postawy $w$ teoriach $i$ stosowanych badaniach spotecznych, in Teorie postaw, S. Nowak. (ed.), Warsaw 1973, pg. 23. 
Pastoral theology

as well as a function of a system of shared moral values. On a cultural level, the privatization of human sexuality, consumeristic and permissive attitudes in marriage, as well as changes in the way families are formed manifest this transformation. ${ }^{27}$ When referring to Western analysts, sociologists speak about the phenomenon of the so-called "institutionalized individualization" in reference to the family. This institutionalized individualization refers to the structural transformation of social institutions that has established new relationships between the individual and society. Institutions, educational systems, and the market directly address the individual and change the norms of its daily life, particularly with regard to the choices that the individual makes in his intimate life. ${ }^{28}$

New issues are arising that go beyond the structural and demographic transformations that are occurring in families. Currently, models of the family that differ greatly from the traditional model based on Christian culture and its value system are becoming more commonplace. Postmodernism has destabilized the Christian concept of the family as a community based on the marriage covenant between a man and women who are open to welcoming children, and secularized models of married life and family are being promoted throughout the world. Gender ideology's promotion of the sociocultural concept of gender identity is another component of postmodern ethics. This concept upholds that men and women have a seemingly great number of options regarding their gender identity from which to choose. According to this ideology, the individual must be guaranteed the ability to choose his own social role and sexual identity and behavior at every moment. M. Peeters points out that "according to the new ethic, people who live together arbitrarily, call themselves a family, and accept their mutual obligations in order to ensure the well-being of the other person must equally be considered a basic social unit, meaning a family." ${ }^{29}$

The Catholic Church's teachings strongly emphasize the value of chastity before marriage, marriage itself, family, and human life from the moment of conception to natural death. Although society accepts non-sacramental, partner, and same-sex so-called "marriages," these are modern threats to the institution of marriage and the family about

$27 \quad$ K. Slany, Alternatywne formy życia matżeńsko-rodzinnego, in Jedna Polska? Dawne inowe zróżnicowania społeczne, A. Kojder (ed.), Cracow 2007, pgs.247-252. mechanizmy dziatania, Warsaw 2010, pg. 97. 
which the Church is legitimately concerned. ${ }^{30}$ Marriage and family morality entail a number of norms that regulate behaviors in this area of life. Observing these norms guarantees order and harmony in the family, which is why these norms should be highly valued both in and by society. The majority of these norms have their roots in religion. Moreover, these standards have been passed down via tradition for generations and have proven to be worthwhile to imitate. In this way, they are treated as moral values that are deeply rooted in society. ${ }^{31}$ Individuals have internalized this moral teaching for decades. Today, however, simple observation points out that many Catholics currently do not follow the Church's moral doctrine on the moral order of married and family life. This moral order ensures that individuals develop harmoniously and in accordance with the ethical norms that regulate the Christians' lives and acts within various social institutions, including the family and marriage. ${ }^{32}$

Many studies on religiosity and morality ask questions about people's attitudes toward marriage and family moral norms. In Poland, a nationwide survey entitled Polski Pomiar Postaw i Wartości [Polish Measures of Attitudes and Values] was conducted in 2009 to ascertain the characteristics of Polish society. Individuals who participated in the survey were asked to rank behaviors and views concerning marriage and family life according to the following: acceptable, it depends, unacceptable. The results were as follows: $18.4 \%$ of respondents thought that "free love" and unlimited sex were acceptable; $19.6 \%$ expressed that such behavior "depends" on the situation; and $48.4 \%$ believed that such behavior is unacceptable. Regarding other behaviors, the survey found the following: cohabitation (31.8\%-acceptable, $23.2 \%$ - it depends, $34.9 \%$ — unacceptable); engaging in sexual intercourse while officially engaged to be married (44.8\%-acceptable, $22.3 \%$ —it depends, $23.3 \%$ - unacceptable); sexual intercourse before sacramental marriage (51.0\% — acceptable, 20.3\% — it depends, $19.1 \%$ unacceptable); contraception (47.6\%-acceptable, $21.7 \%$-it depends, $22.7 \%$ - unacceptable); in vitro fertilization (30.7\%-acceptable, $20.3 \%$ —it depends, $36.5 \%$ - unacceptable). The respondents were more rigorous in their responses to issues pertaining to: marital infidelity

$30 \quad$ S. H. Zaręba, W kierunku jakiej religijności. Studia nad katolicyzmem polskiej młodzieży, Warsaw 2008, pg. 284.

31 K. Ryczan, Wartości katolików a typ środowiska miejskiego. Lublin 1992, pg. 152

32 S. H. Zaręba, W kierunku jakiej religijności. Studia nad katolicyzmem polskiej młodzie ży, pg. 283. 
Pastoral theology

(2.5\%—acceptable, $6.4 \%$ —it depends, $85.0 \%$ —unacceptable); divorce (12.3\% - acceptable, $32.25 \%$ —it depends, $49.3 \%$ - unacceptable); abortion (6.7\%-acceptable, $21.7 \%$-it depends, $64.9 \%$ - unacceptable), euthanasia (12.1\%-acceptable, 20.6\%-it depends, 57.6\%-unacceptable); and homosexuality (15.6\%-acceptable, $9.7 \%$-it depends, $61.9 \%$ - unacceptable). ${ }^{33}$ In 2013 , a nationwide survey that included 828 individuals who considered themselves Catholic was conducted in Poland; this survey considered the same issues as those listed above. When questioned, the Catholic participants responded to ethical issues pertaining to marriage and family life in the following way: almost three-quarters $(74 \%)$ of the respondents were more or less in favor of sexual intercourse before marriage, while $21 \%$ more or less opposed sex before marriage. With regard to other ethical areas of marriage and family life, the respondents answered as follows: contraceptive use (77\%—favored, 17\%—opposed); divorce (63\%—favored, 34\%—opposed); abortion (27\%-favored, $65 \%$-opposed); homosexual sexual relations ( $22 \%$-favored, $70 \%$ - opposed); married spouses engaging in sexual intercourse with a person other than a spouse $(9 \%$-favored, $89 \%$-opposed). ${ }^{34}$

A similar nationwide survey on issues pertaining to marriage, family life, and sex was conducted in Poland among youth who had completed middle school. How did these students respond as they were considering whether to continue their studies or enter the workforce? In 2013, $14 \%$ of the students agreed with the statement "One should have sexual intercourse for the first time only after entering into marriage," while $64 \%$ of students disagreed with this statement, and $22 \%$ did not have an opinion on this subject. In 2016, $11 \%$ of students agreed with the same exact statement, $70 \%$ disagreed, and $19 \%$ did not have an opinion on the subject. In 2013, $73 \%$ of students agreed with the statement "Marriage is not necessary in order for two people who love each other to enter into a sexual relationship," while $14 \%$ of students disagreed with this statement, and $13 \%$ did not have an opinion on the subject. In $2016,77 \%$ of students agreed with the exact same statement, $11 \%$ disagreed, and $12 \%$ did not have an opinion on this subject. In both 2013 and 2016, students were also asked to evaluate the statement "love and marriage are not necessary to engage in sexual intercourse; even a fleeting relationship can provide pleasurable and beautiful experiences." In 2013, 31\% of students agreed with this same statement,

$33 \quad$ S. H. Zaręba, Globalny profil postaw moralnych Polaków, pg. 121

34 Religiosity and Moral Principles, A Message from the CBOS, 15/2014. Edited by R. Boguszewski, Warsaw 2014, pg. 13. 
$52 \%$ disagreed, and $16 \%$ did not have an opinion on this matter. Three years later, in $2016,35 \%$ of students agreed with this exact same statement, $47 \%$ disagreed, and $18 \%$ did not have an opinion on the issue. Moreover, among the respondents of the 2016 survey, more girls than boys (14\% vs. $9 \%$ ) approved of the first and second statements, while mostly boys compared to girls (47\% vs. $21 \%$ ) agreed with the third statement. The author of the report made the following comments on the survey results: "Although small, the changes that have taken place Pastoral in the consciousness of [Polish] youth in the last three years reveal a common trend: they are in favor of greater sexual permissiveness. The changes in the attitude of youth demonstrate that the youth are distancing themselves from traditional values in this [sexual] sphere." ${ }^{35}$

With regard to social discussions on the protection of human life, two-thirds of the Poles surveyed (66\%) agreed with the statement that "Human life should be protected from conception to natural death in every situation regardless of the circumstances," $28 \%$ disagreed, and $6 \%$ did not have an opinion on this subject. Among women up to 49 years of age, $64 \%$ of the respondents agreed with this statement, $32 \%$ disagreed, and $4 \%$ did not respond. ${ }^{36}$ Taking into account the nationwide polls as well as some environmental research on Catholic marriage and family ethics, the sociologist of morality J. Marianski noted: "One could generally estimate that, among the youth in Poland, about $25 \%$ of respondents approve of the values and norms of Catholic marriage and family ethics, $50 \%$ are selective about which norms they agree, and $25 \%$ are completely opposed to this morality. With regard to all of [Polish] society, about $40 \%$ of respondents approve of these values, $40 \%$ partially approve, and $20 \%$ are completely opposed to these values and norms." 37

To summarize the two points made above, general moral attitudes translate into views and behaviors in concrete situations and matters. In addition, if one considers what people declare as the faith that they follow, then it is obvious that the sexual morality of Poles does not correspond with the precepts of their faith and from the institutionalized requirements of the Church. This is certainly a sign of postmodernity, where clear moral models, codes, and principles are increasingly

35 M. Gwiazda, Młodzież $i$ seks, in Młodzież 2016. Opinie $i$ diagnozy, nr 38, M. Grabowska, M. Gwiazda (eds.), Warsaw CBOS 2017, pgs. 165-166.

36 Opinions on the Permissibility of Abortion, A Message from the CBOS, nr 51/2016. Edited by M. Herrmann, Warsaw 2016, pgs. 2-3.

37 J. Mariański, Religia i moralność w świadomości Polaków. Zależność czy autonomia, pgs. 20-21. 
scarcer. This does not mean, however, that people should be given unlicensed freedom to create their own life story, but it does signify, however, that we are transitioning from an era that acknowledges and refers to predetermined "reference groups" to an era where everyone compares and weighs their options and in which the ultimate goal of self-creation is primarily and irrevocably undetermined, unknown, and subject to frequent and significant changes. ${ }^{38}$

\section{Conclusion}

The statistical characteristics of the moral dimension of the religiosity of contemporary Poles presented briefly above reveals that there is a discrepancy between the Catholic Church's moral requirements and what contemporary faithful Poles think and how they behave. Religious factors that justify moral actions are weakening, thereby revealing that ethical individualism and relativism is gaining a stronghold in the consciousness of Poles, especially the youth. Many sociological studies confirm that Polish people's approach to marital and family morality, especially with regard to the norms that regulate sex, is the most subjective and contentious. In sociological studies on religiosity and morality, a methodological and "cold" approach is necessary. For example, a pastoral theologian would look at the results of such a survey differently than a pastor or catechist. A sociologist must evaluate social phenomena, and the data from sociological research should help the sociologist develop strategies to proceed. Democratic progress, the development of a capitalist liberal economy, social modernization, and a higher standard of living do not necessarily lead to the secularization of society. The high value that Poles place on the family in the context of other values demonstrates that it is highly likely that pastoral ministry will positively influence the views of Poles. This is the case in almost all sociological studies on this subject conducted in Poland.

Pastoral theologians and priests who serve on the front lines should be convinced that they are going out to serve not only Christians, but also the many other people in Polish society who are distant from the Church, but who, as evidenced by religious studies, have not completely broken their ties with it and who, like Zacchaeus, would like to "see Jesus." It is necessary for pastors to reach out to these individuals through different forms of specialized pastoral work. The Church also needs to implement its social mission to shape the religiosity of Poles in area of morality through pastoral ministry. To this end, the 
Church must not only implement certain activities, but also assess the current affairs of social life and express its assessment from the pulpit. These issues should be presented in a thoughtful and objective manner that is based on the Gospel and in accordance with the Church's social teaching. The grim results of sociological studies on morality can sometimes depress ethicists and zealous Catholics. In this case, it is important to realize that the indicators of attitudes, the acceptance of norms, and opinions do not exhaust the truth about the moral condition of man. For, the Creator has inscribed into man's very being an objective "moral code." In its concern for man, the Church is called to help him interpret this code and to teach man how to follow it in the concrete cultural conditions in which he lives.

\section{MORALNY WYMIAR RELIGIJNOŚCI POLAKÓW W DOBIE TRANSFORMACJI SYSTEMOWEJ}

W artykule autor omówił wybrane wskaźniki statystyczne, dotyczące moralnego wymiaru religijności współczesnych Polaków. Pokazał, że obecnie większość respondentów (59\%), choć opowiada się za potrzebą posiadania zasad moralnych, to jednak skłonna jest od nich odstąpić pod wpływem okoliczności. Blisko połowa (48\%) kieruje się wyłącznie własnym sumieniem, odrzucając potrzebę uzasadnienia moralności przez religię. Słuszność wszystkich lub większości zasad moralnych katolicyzmu uznaje łącznie $71 \%$, ale nie ze wszystkimi się zgadza. W ocenie konkretnych norm katolickiej etyki małżeńskiej i rodzinnej wykazano małą akceptację normy czystości przedmałżeńskiej, katolickiej nauki na temat regulacji poczęć. Większym poszanowaniem cieszyła się wartość wierności małżeńskiej, trwałości związku, poszanowania poczętego życia. Ostateczną konstatacją autora było twierdzenie, że współczesne transformacje społeczne pogłębiają rozdźwięk pomiędzy religią i moralnością na co dzień.

Słowa kluczowe: religijność, moralność religijna, normy moralne, pluralizm, transformacja systemowa.

\section{Bibliography:}

1. Bauman Z., Ptynna nowoczesność, trans. T. Kunz, Cracow 2006.

2. Boguszewski R., Religia i moralność, in Leksykon socjologii moralności. Ed. J. Mariański, Cracow 2015, pgs. 659-666.

3. Borowik I., Doktór T., Pluralizm religijny i moralny $w$ Polsce. Raport $z$ badań, Cracow 2001. 
Pastoral theology

4. Dyczewski L., Kultura w całościowym planie rozwoju, Warsaw 2011.

5. Gwiazda M., Młodzie $\dot{z} i$ seks, in Młodzież 2016. Opinie i diagnozy nr 38., (ed.) M. Grabowska, M. Gwiazda, Warsaw CBOS 2017, pgs. 165-170.

6. Jarmoch E., Wiara i religijność, in Postawy społeczno-religijne Polaków 1991-2012, (eds.) L. Adamczuk, E. Firlit, W. Zdaniewicz, Warsaw 2013, pgs. 29-57.

7. Jasińska-Kania A., Przeksztatcenia moralności $w$ Polsce i Europie, in Wymiary życia społecznego. Polska na przełomie XX $i$ XXI wieku, (ed.) M. Marody, Warsaw 2004, pgs. 397-418.

8. Krzyżanowska Ł., Stec M., Rynek pracy, in Wspótczesne społeczeństwo polskie, (eds.) A. Giza, M. Sikorska, Warsaw 2013, pgs. 523-571.

9. Mariański J., Przemiany moralności polskich maturzystów w latach 19942009. Studium socjologiczne, Lublin 2011.

10. Mariański J., Religia i moralność w świadomości Polaków: Zależność czy autonomia?, "Konteksty społeczne," vol. 3 (2015) no. 1.

11. Moral Principles and Religion, A Message from the CBOS nr 4/2017, Warsaw 2017, pg. 2, edited by R. Boguszewski.

12. Neuner P., Psychospołeczne i polityczne uwarunkowania chrześcijaństwa dziś, in Chrześcijaństwo jutra. Materiaty II międzynarodowego kongresu teologii fundamentalnej, Lublin, September 18-21, 2001, (eds.) M. Rusecki et al., Lublin 2001, pgs. 230-265.

13. Nowak S. Pojęcie postawy $w$ teoriach $i$ stosowanych badaniach społecznych, in Teorie postaw, (ed.) S. Nowak, Warsaw 1973.

14. Opinions on the Permissibility of Abortion, A Message from the CBOS, nr 51/2016. Edited by M. Herrmann, Warsaw 2016.

15. Peeters M. A., Globalizacja zachodniej rewolucji kulturowej. Kluczowe pojeccia, mechanizmy działania, Warsaw 2010.

16. Piwowarski W., Socjologia religii, Lublin 2000.

17. Piwowarski W., Od Kościoła ludu do Kościoła wyboru, in Od Kościoła ludu do Kościoła wyboru. Religia a przemiany społeczne w Polsce, (eds.) I. Borowik, W. Zdaniewicz, Cracow 1996 pgs. 9-16.

18. Piwowarski W., Przemiany Kościoła ludowego w Polsce, "Przegląd Humanistyczny" 4:1997, pgs. 17-23.

19. Podgórecki A., Socjologiczna teoria prawa, trans. Ł. M. Kwaśniewska, R. Smogór, Warsaw 1998.

20. Rosik S., Wezwania i wybory moralne, Lublin 1992.

21. Ryczan K., Wartości katolików a typ środowiska miejskiego, Lublin 1992.

22. Sareło Z., Postmodernizm w pigułce, Poznań 1998.

23. Slany K., Alternatywne formy życia matżeńsko-rodzinnego, in Jedna Polska? Dawne i nowe zróżnicowania społeczne, (ed.) A. Kojder, Cracow 2007, pgs. 237-268.

24. Stark R., Glock C., Wymiary zaangażowania religijnego, in Socjologia religii. Antologia tekstów, (ed.) W. Piwowarski. Cracow 1998, pgs. 182-187.

25. Szlendak T., Socjologia rodziny. Ewolucja, historia, zróżnicowanie, Warsaw 2011. 
26. Święs K., Aktualne uwarunkowania nowej ewangelizacji w Polsce, in Polskie drogi nowej ewangelizacji, (eds.) K. Swięs, D. Lipiec, Lublin 2014, pgs. 21-56.

27. Wnuk-Lipiński E., Ziółkowski M. (ed.), Pierwsza dekada niepodległości. Próba socjologicznej syntezy, Warsaw 2001.

28. Zaręba S. H., Globalny profil postaw moralnych Polaków, in Rodzina. Religia. Społeczeństwo. Polacy 2009 w diagnozie socjologicznej, (ed.) S. H. Zaręba, Warsaw 2010, pgs. 115-138.

29. Zaręba S. H., W kierunku jakiej religijności? Studia nad katolicyzmem theology polskiej mtodzieży, Warsaw 2008.

30. Ziółkowski M., Zmiany systemu wartości, in Wspótczesne społeczeństwo polskie. Dynamika zmian, (ed.) J. Wasilewski, Warsaw 2006, pgs. 145-174. 